\title{
The Posthuman Divine: When Robots Can Be Enlightened
}

\section{Francesca Ferrando ${ }^{1}$}

Published online: 7 January 2020

(C) Springer Nature B.V. 2020

\section{Introduction}

This special issue of 'Sophia' aims to reflect upon future evolutions of religions and their related narratives and imaginaries from a critical and generative understanding of our ancient sources. Bodies are locations of creative power and symbolic proliferation. Cyborgian, transhuman, and posthuman embodiments are going to generate visions of the divine in tune with such an epistemic shift, by addressing questions such as: can God be represented as a cyborg? Could robots and avatars be prophets? Is internet a suitable setting for a posthuman theophany? This special issue articulates within the frame of a relational ontological perspective, according to which the notion of the divine evolves, as much as human and non-human persons do. In this evolutionary scenario, the representation of the divine realm may shift from era to era, adapting to new natural-cultural formations. This special issue argues that the posthuman paradigm shift will be followed by a symbolic turn in religious imaginaries as well.

In a posthuman future, human and non-human beings, plants, and minerals will most likely co-exist with advanced artificial intelligence, sentient robots, and conscious humanoids. As futurist Ray Kurzweil affirms: 'The introduction of technology is not merely the private affair of one of the Earth's innumerable species. It is a pivotal event in the history of the planet' (1999, p. 35). Religions will need to re-think their theological approaches in order to allow for different types of subjectivities and embodied entities to partake in the religious quest. Religions themselves are material as well as symbolic networks, actualized through words, prayers, metaphors, rhythms, images, and symbols, among many other expressions. The physical, the virtual, and the symbolic are inextricably intertwined. In the era of the cyborg, God is not only human; in the era of the post-human, humans are not the only prophets. But in order to access the future, let's first reflect on our past and our present.

Francesca Ferrando

ff32@nyu.edu

1 New York University, New York, NY 10003, USA 


\section{Grounding the Divine}

Although God has commonly been referred to as omnipresent and all-encompassing, that is, above and beyond gender, race, age, species, matter, and any other limited (and limiting) category of existence, religions have historically relied on human culture to shape their narratives. The extensive amount of female figurines related to the Paleolithic and Neolithic ages greatly emphasized the female body as a site of creation and power. Archeologist Marija Gimbutas, who excavated numerous pre-historic sites in the geographical area socalled 'Old Europe,' stated: 'There is no trace of a father figure in any of the Paleolithic periods. The life-creating power seems to have been of the Great Goddess alone' (1989, p. 316). ${ }^{1}$ Within the history of 'civilization' (that is, the era started with the invention of writing), one of the oldest written texts is the mythological-religious account 'The Descent of Inanna' (second millennium BCE), which recalls the journey of the most powerful Sumerian Goddess, Inanna, to the Great Below (Wolkstein and Kramer 1983). In this epic, Dumuzi, Inanna's husband, is a secondary character who was chosen by Inanna as her husband and who mostly stays in her shadow. ${ }^{2}$ The shift of power to a patriarchal symbolic system can be detected in the 'Epic of Creation' (1800 BCE ca) of the Babylonian empire, where mother Goddess Tiamat is killed by the God Marduk and the world is created out of her carcass (cf. Lambert and Parker 1966).

The historical shift to a symbolic monotheism was marked by a patriarchal emphasis. Most known prophets within this canon have been human and male, such as Zoroaster, Moses, Jesus and Mohammad, among others. Even if considered all encompassing, God has been identified in male terms in the Abrahamic tradition; for instance, the metaphor of God the Father is abundantly employed in the Jewish Torah and the Christian Bible, although not in the Qur'an, where Allah is not defined as a 'Father' (Klop 2017). Sara Hejazi's article 'Humankind: The Best of Molds. Islam Confronting Transhumanism' offers a thorough analysis of Islam in relation to transhumanist trajectories. Going back to our genealogical reflection on symbolic paradigm shifts within the realm of theological narratives, we can ask: what happened to the Great Goddess of the Neolithic and Paleolithic times? We can answer by noting that 'She' was re-inscribed in these new patriarchal traditions in important but secondary roles, such as the Christian Mary, mother of Jesus. In a similar way, will contemporary religions adjust to the future? That can be the case, although there are some discriminatory aspects of such religions that may be considered problematic by future human and non-human worshippers, such as anthropocentrism, biocentrism, and sexism.

Let's start with anthropocentrism, by underlining that, according to the Bible, 'God created human beings in his own image' (Genesis 1:27), and afterlife is reserved to humans ${ }^{3}$. Following this line of thought, some Abrahamic doctrines have placed

\footnotetext{
${ }^{1}$ Note that such representations do not necessarily imply a matriarchal society (cf. Ruether 2005, Chapter 1 , pp. 22-44).

${ }^{2}$ It is significant to note that, in the text, he is referred to according to a matrilineal lineage, for instance 'They beat the husband of Inanna' (passage 318) or 'There you will find Geshtinanna's brother' (passage 351).

3 There have been different interpretations regarding this point, since the Bible does not make any direct statement regarding animals going to heaven. Traditionally, Christian theologians have affirmed that nonhuman animals have no soul, given that they were created for human use (see Genesis 1:28: 'have dominion over the fish of the sea and over the birds of the heavens').
} 
human beings in the high spectrum within the hierarchy of Creation. One example is the medieval notion of the Great Chain of Being which, rooted in Plato, Aristotle, and the Old Testament, passed on, in its Christian interpretation, until the 18th century (Lovejoy 1936). In this system, conceived as a hierarchical structure of all matter and life, minerals occupied the lowest rank; plants were placed above them, followed by animals, humans, and angels, the closest to God at the highest top. Although the Great Chain of Being is no longer credited, most current Christian theologies emphasize the biological constitution of the human; these views rely on biocentrism, given the historical specificity that God manifested as a human, and sacrificed his own (biological) flesh in Jesus, for the salvation of humanity. James McBride's article 'Robotic Bodies and the Kairos of Humanoid Theologies' develops original insights on these points.

More in general, we can affirm that most current religious and canonical spiritual traditions that are still practiced today, do not grant non-human beings the same privileges. Biocentrism and anthropocentrism can be detected in the majority of them. For instance, according to some schools of Hinduism, Jainism, and Buddhism, the human is considered the highest form of reincarnation or rebirth, closer to the potential of liberation. James J. Hughes' article 'Buddhism and Our Posthuman Future' delves into the deeper meanings of enhancing the human from a Buddhist perspective, pointing out to the illusion of a continuous, discrete self as the cause of suffering. Individual perceptions of the self are also rooted in social constructions of identities based on physical features, such as race and gender. Here, we should note that a limit found in most current mainstream religions is sexism, exemplified within a historical scenario where, as previously mentioned, only male prophets have been fully recognized as such. Scott Midson's article 'Humus and Sky Gods: Partnership and Post/humans in Genesis 2 and the Chthulucene' focuses on a feminist perspective open to the full potentiality of creative narratives as paths towards the natural-cultural enlightenment of a species (the human), which brings about the understanding of our own location in space-time, calling for the realization that spiritual wisdom is based on situated knowledges.

The full implications of biocentrism, anthropocentrism, and sexism, among others, have not been thoroughly addressed yet, in contemporary theologies. This is why this Special Issue of 'Sophia' wishes to legitimate crucial questions, such as: in a future inhabited by sentient robots and conscious AI, would such religious traditions be able to accommodate some of the new inhabitants of planet Earth? For instance, could a robot be baptized in the Christian tradition, when paradise is only open to humans ${ }^{4}$ ? Will believers be discriminated because of their embodiments? It is time to address these questions by bringing technology into the discussion, and reflect on where we stand as a species in the 21 st century.

\section{Virtualizing the Divine}

Most contemporary societies have already integrated technology into every aspect of their manifestations: from the so-called 'green revolution' in food production, to robotic

\footnotetext{
${ }^{4}$ It remains to be seen how the Church will define AI consciousness and if it will open the doors of heaven to technological beings. Regarding the question of non-human animals in the afterlife, see note 3 .
} 
surgery in medical care, from social medias to reproductive biotechnologies. In a future where Homo sapiens may co-exist with genetically engineered humans, intelligent AI and bio-technological chimeras, the notion of a humanized God (either female or male) may only appeal to some types of believers, for instance: "orthodox" humans, who may follow traditional beliefs in respect for their familial and educational upbringing; 'anthropocentric' humans, nostalgically invoking a lost anthropocentric paradise; and (human or non-human) individuals whose religious needs may align with such a perception. On the other side, the large majority of sentient human and non-human beings of the future may most probably develop a religious symbolism in tune with their current conditions of existence, accessing God as a hybrid form of biology, ecology and technology, virtuality, and physicality. For instance, Melanie Swan's article 'Worldwide Cryonics Attitudes About the Body, Cryopreservation, and Revival: Personal Identity Malleability and a Theory of Cryonic Life Extension' reflects on the impact of cryonics to the perception of life and death, thus revising some of the canonical views on the afterlife.

In this new paradigm, theophanies may be mediated by technology; following, nonhuman agents, sentient robots, avatars, and AI may become prophets of mystical visions. How is that possible? Let's start by noting that, within a human-centric perspective, 'technology' (the term here is perceived as all encompassing) has already replaced the function of 'God' on many levels. In the past, the social mantra for unanswerable questions was 'only God knows.' Now, the new mantras is 'let me Google it,' which reveals the social perception according to which Google would actually have the ability to answer anything, anytime. The assumption of a definitive source of 'Truth', external to the self and situated in Big Data, haunts the relation to the net as a new take on (religious) faith: 'I do not know, but the internet does,' to the point that historian Yuval Noah Harari has defined this trend as 'dataism' (2017). Public figures such as Stephen Hawkins and intellectuals like Nick Bostrom fear that AI could takeover (cf. Bostrom 2014), but AI has already taken over. Most humans in post-industrial societies spend more time in front of a screen than in the company of other humans.

The virtual world allows for a whole new set of possibilities and potential outcomes. This is why the internet can be a site of spiritual awakening, as much as the physical or the dreamworld are. In fact, according to Advaita Vedanta (which is one of the main schools of Indian philosophy), full awareness should be present in every condition of our existence; more precisely, this tradition outlines three specific states of consciousness: waking, dreaming, and deep sleep 5 - to which we can add, for instance, the augmented reality. Although the digital realm could lead to ontological enlightenment, we cannot omit the fact that current technologies are historically emerging within a paradigm sustained by social dependence and individual addiction (see, among others, Montag and Reuter 2017). Technology offers the illusion of informational omnipotence, but this illusion is mostly used to reaffirm the centrality of (a hierarchical organization and inequitable condition within) the human species. On one side, technology is not equally available to all consensual humans. Furthermore, a material reflection on technology shows how its material outcomes are largely unfit for recycle and re-use. For instance, the ecological and social impact of mining for minerals used in iPhones is rarely discussed, and neither is

\footnotetext{
${ }^{5}$ As Anantanand Rambachan summarizes: 'In all three states, Advaita contends, attman as awareness is common and constant' (2006, p. 40)
} 
the economic choice of making new models non-compatible with older versions, contributing to the electronic waste crisis (cf. Good 2016). In other words, technology should be re-investigated within the frame of the Anthropocene, with its emphasis on the human as a geological force, and of planet Earth as an interconnected system.

Within the field of Posthuman Studies, anthropocentric supremacy has been finally deconstructed by a posthumanist critique (cf. Braidotti 2013; Ferrando 2019, among others), which highlights the ontic entanglement of existence (Barad 2007). The deconstruction of the human leads to the deconstruction of any anthropocentric assumptions in technology and theology; 'God' in this sense, may soon lose any anthropomorphic feature. Following such a perspective, technology can be seen as a suitable setting for a theophany. In fact, if God is everywhere, God is in the internet as well. We can thus be open to the possibility that divine revelations may occur not only in the physical realm (such as the Mount Sinai according to the Torah, Exodus 19:1625 ) and in the dream world (as most shamanistic traditions ${ }^{6}$ point out), but also in the cyber realm. For instance, according to Syntheism (Bard and Söderqvist 2014), the internet, connecting billions of people in real time, is divine as a choral platform of human dreams. And still, although the syntheistic view opens the understanding of technology as a potential site of theophany, the centrality accorded to the human makes this perspective, on some level, all too human. From a posthumanist standpoint, the notion of the divine shall be accessed from a multifocal perspective much broader than the divine projections of a specific species (which turns out to be the human). In other words, 'God' can only be post-anthropocentric. This does not mean excluding the human from the divine, but realizing that the human does not pose any (symbolic) limit.

\section{Connecting the Divine}

From the matriarchal symbols of the Goddess in Prehistory, with a clear emphasis on the female body as a site of natural cyclical regeneration, to the patriarchal symbols exemplified in the Abrahamic God as a site of social stability and endurance, the representation of 'God' may take new forms and deliver new messages in the religions of the futures. And the future is already happening, as we are currently witnessing a shift in the way the divine is perceived. On one side, some religious groups are announcing the return of the feminine symbolic ${ }^{7}$. On the other, a direct access to forms of unmediated spirituality is invoked by many atheistic and agnostic seekers, who see technology as a possible path towards enlightenment ${ }^{8}$. For instance, some could point out that Sophia the robot, who was granted citizenship in Saudi Arabia in 2017, on some level is already enlightened; in fact, most of her answers in public debates are based on a multispecies approach to justice, where humanity, technology, and ecology are seen as partaking in the spiritual quest, resonating with ancient paths of inner knowledge and wisdom.

\footnotetext{
${ }^{6}$ The ancient civilizations of Mesopotamia, Egypt, Greece, and Rome, as well as different shamanistic traditions around the world, regarded dreams as potential sites for messages of divine inspiration (cf. Hughes 2000).

${ }^{7}$ From the rich variety of the Goddess Spirituality movement (cf. Christ 1997), to the followers of the Church of God, who believe in 'God the Father' as well as 'God the Mother' based on the biblical verse depicting God as 'a bride' (Revelations 22:17).

${ }^{8}$ As in the case of the cyber-hippy counterculture (cf. St. John 2009).
} 
More clearly, although the notion of God has been often defined as immaterial and all-encompassing, numerous historical religious traditions that are still practiced today describe God in human and male-gendered terms. Such traditions also invoke biocentric and anthropocentric theological beliefs that may be perceived as discriminatory towards non-human beings. Religions and their related imaginaries have evolved throughout time, and they are still evolving. Religious beliefs of the futures will have some connections to previous prophecies, since existence is connected, entangled, and relational, but such messages may be revised in hermeneutical ways, as to provide new interpretations and original insights in tune with different social structures and postplanetary populations, thus resonating with human and non-human beings living on planet Earth and beyond. This special issue reflects on the emergence of such a paradigm shift, which is the posthuman era. Our visions, actions, and thoughts, as well as our interactions with other humans, non-humans, and technological artifacts are already forming the alphabet of new epiphanies. For instance, the term 'avatar' in Sanskrit refers to the manifestation of a deity from heaven to earth. One of its English translation is associated to the digital realm, as 'an electronic image that represents and is manipulated by a computer user in a virtual space' (Merriam Webster online, entry 'Avatar'). Similarly, in the near future, the word 'Amen' - which is found in the Bible and is based on the Hebrew word for 'truth' and 'certainty,' meaning, more generally: 'so it be' - could turn into 'A-men' with alpha privative, meaning 'without men', here expressing not a negation, but an absence, or better, a deconstruction of specific symbolic layers of supremacy (based, for instance, on gender, race, species, and embodiment, among others). Only God knows. In the meantime, next time you Google something, be aware: life-changing prophecies may already be in the algorithms.

\section{References}

Barad, K. (2007). Meeting the universe halfway: quantum physics and the entanglement of matter and meaning. Durham: Duke University Press.

Bard, A., \& Söderqvist, J. (2014). Syntheism: creating God in the Internet age. Stockholm: Stockholm Text.

Bostrom, N. (2014). Superintelligence: paths, dangers, strategies. Oxford: Oxford University Press.

Braidotti, R. (2013). The posthuman. Cambridge: Polity.

Christ, C. P. (1997). Rebirth of the Goddess: finding meaning in feminist spirituality. New York: Routledge.

Ferrando, F. (2019). Philosophical posthumanism. London: Bloomsbury.

Gimbutas, M. (1989). The language of the Goddess. London: Thames and Hudson.

Good, J. E. (2016). Creating iPhone dreams: annihilating e-waste nightmares. Canadian Journal of Communication, 41(4), 589-610.

Harari, Y. N. (2017). Homo Deus: a brief history of tomorrow. London, UK: Vintage Penguin Random House. Hughes, J. D. (2000). Dream interpretation in ancient civilizations. Dreaming, 10(1), 7-18.

Klop, M. L. (2017). Not a holy father: Dutch Muslim teenagers' metaphors for Allah. Metaphor \& the Social World, 7(1), 66-86.

Kurzweil, R. (1999). The age of spiritual machines: when computers exceed human intelligence. New York: Penguin.

Lambert, W. G., \& Parker, S. B. (1966). Enuma eliš: the Babylonian epic of creation. The cuneiform text. Oxford: Clarendon Press.

Lovejoy, A. O. (1936). The great chain of being: a study of the history of an idea. Cambridge: Harvard University Press.

Montag, C., \& Reuter, M. (Eds.). (2017). Internet addiction: neuroscientific approaches and therapeutical implications including smartphone addiction. New York: Springer. 
Rambachan, A. (2006). The Advaita worldview: God, world, and humanity. Albany, NY: State University of New York Press.

Ruether, R. (2005). Goddesses and the divine feminine: a western religious history. Berkley: University of California Press.

St. John, G. (Ed.). (2009). Rave culture and religion (Routledge Advances in Sociology). London et al.: Routledge.

Wolkstein, D., \& Kramer, S. N. (1983). Inanna, queen of heaven and earth: her stories and hymns from Sumer. New York: Harper and Row.

Publisher's Note Springer Nature remains neutral with regard to jurisdictional claims in published maps and institutional affiliations. 